УДК 336.763

Вахлакова В.В., к.е.н., старший викладач кафедри економіки і підприємництва Східноукраїнського національного університету ім. В.Даля

Овечкіна О.А., к.е.н., доцент кафедри економіки і підприємництва Східноукраїнського національного університету ім. В.Даля

\title{
ФІНАНСОВО-ЕКОНОМІЧНА БЕЗПЕКА ЯК ОСНОВА РОЗВИТКУ ЕКОНОМІКИ УКРАЇНИ
}

Стаття присвячена питанням ролі фінансово-економічної безпеки в будуванні управлінського процесу для забезпечення сталого розвитку країни в умовах відкритої економіки. Розглянута роль управління в забезпеченні сталого розвитку держави. Визначені стратегічні методи, спрямовані на досягнення національних інтересів держави в сучасних умовах і формування концепції національної безпеки країни. Розглянуто поняття «безпека» в цілому. Визначені ії окремі елементи. Здійснено аналіз складових фінансово-економічної безпеки держави в умовах відкритої економіки. Визначені умови забезпечення фінансово-економічної безпеки на сьогоднішній день. Розглянуто вплив існуючих економічних теорій на формування системи фінансовоекономічної безпеки держави. Запропоновані принципи побудування фінансовоекономічної безпеки як елемента національної безпеки держави в сучасних умовах.

Ключові слова: фінансово-економічна безпека, сталий розвиток, ринкові відносини, відкрита економіка, економічна система, глобалізація.

Літ. 6

Вахлакова В.В., Овечкина О.А.

\section{ФИНАНСОВО-ЭКОНОМИЧЕСКАЯ БЕЗОПАСНОСТЬ КАК ОСНОВА РАЗВИТИЯ ЭКОНОМИКИ УКРАИНЫ}

Статья посвящена вопросам роли финансово-экономической безопасности в построении управленческого процесса для обеспечения устойчивого развития государства в условиях открытой экономики. Рассмотрена роль управления в обеспечении устойчивого развития государства. Определены стратегические методы, направленные на достижение национальных интересов государства в современных условиях и формирования концепции национальной безопасности страны. Рассмотрено понятие «безопасность» в целом. Обозначены ее отдельные элементы. Осуществлен анализ составляющих финансово-экономической безопасности государства в условиях открытой экономики. Определены условия обеспечения финансово-экономической безопасности на сегодняшний день. Рассмотрено влияние существующих экономических теорий на формирование системы экономической безопасности государства. Предложены принципы построения системы финансово-экономической безопасности как элемента национальной безопасности государства в современных условиях.

Ключевые слова: финансово-экономическая безопасность, устойчивое развитие, рыночные отношения, открытая экономика, экономическая система, глобализация 
Vakhlakova V., Ovechkyna E.

\section{FINANCIAL AND ECONOMIC SECURITY AS A BASIS FOR DEVELOPMENT OF THE ECONOMY OF UKRAINE}

The article is devoted to the question of the role of financial and economic security in the construction of a managerial process to ensure sustainable development of the country in an open economy. The role of management in ensuring sustainable development of the state is considered. Strategic methods aimed at achieving the national interests of the state in modern conditions and forming the concept of national security of the country are defined. The concept of "safety" as a whole is considered. Determined its individual elements. The analysis of components of financial and economic security of the state in the conditions of an open economy is carried out. The conditions of providing financial and economic security for today are determined. The influence of existing economic theories on the formation of the system of financial and economic security of the state is considered. The proposed principles of the construction of financial and economic security as an element of national security in the modern conditions.

Key words: financial and economic security, sustainable development, market relations, open economy, economic system, globalization.

Постановка проблеми. Важливішу роль в побудові управлінського процесу для забезпечення сталого розвитку держави варто відвести стратегічним методам, які спрямовані на досягнення національних інтересів держави в умовах посилювання загальносвітових загроз і формалізовані в концепції національної безпеки країни. Наявність системи фінансово-економічної безпеки, що сприяє захисту підприємства від загроз, є важливішою умовою забезпечення стійкого зростання результатів фінансової діяльності підприємства. Тому забезпечення фінансово-економічної безпеки підприємств на сьогоднішній день є надзвичайно актуальним для України.

Аналіз останніх досліджень та публікацій. Основні теоретичні засади фінансово-економічної безпеки підприємств досліджуються у світовій та вітчизняній науковій літературі. Серед зарубіжних та вітчизняних науковців, які досліджували цю тему, варто виділити таких як О.В. Ареф’єва, О.І. Барановський, А. Бєрл'є, Ю.С. Благов, Ш.М., Бондарчук Н.В., Валітов, О. Вільямсон, М. Дженсен, О.В. Деменок, Квасова О.П., Матвєєв В.В., К. Мерфі, Н.В. Наконечна. Є.А. Олійникова, І.О. Тарасенко, О.В. Черниш та ін. Однак незважаючи на популярність поняття «фінансовоекономічна безпека», до сьогодні серед вчених існують розбіжності щодо його сутності.

Мета статті - визначення сучасного прояву сутності фінансово-економічної безпеки як основи розвитку економіки держави.

Виклад основного матеріалу дослідження. Термін «безпека» $\epsilon$ загальносистемним, якій в цілому відображає завдання забезпечення сталого розвитку країни як єдиної незалежної держави відповідно встановленим пріоритетам i національним цілям в умовах всеосяжної глобалізації фінансової та економічної систем держави [1]. Слід зазначити, що в їі межах спостерігаються суттєві протиріччя, формуються загрози стабільного розвитку і цілісності країни.

Одним 3 найголовніших елементів національної безпеки держави $є$ фінансовоекономічна. Практично не існує жодного аспекту національної безпеки країни, які б не залежали від рівня її фінансової та економічної безпеки. 
Існує безліч наукових робіт, присвячених дослідженню проблем економічної безпеки. Питанням фінансової безпеки приділяється значно менше уваги, спроби виявити специфіку і склад загроз, які можуть завдати їй істотної шкоди, носять досить фрагментарний характер. Фінансова безпека частіше розглядається як складовий елемент економічної. В процесі іiї дослідження не враховується ряд базових принципів, і методів аналізу взаємозалежного функціонування фінансової та економічних систем.

У зв'язку з цим на сьогодні немає однозначного трактування поняття фінансовоекономічної безпеки, що визначає його дискусійний характер [2].

Прийнято розглядати окремо фінансову і економічну безпеку як невід'ємні складові національної безпеки. Незважаючи на велику взаємопов'язаність цих понять, вони не розглядаються як рівнозначні елементи єдиного цілого. В сучасних умовах зростаючих ризиків та загроз ефективність політики національної безпеки держави по досягненню інтересів може бути визначена тільки за допомогою синергетичних ефектів від взаємодії iї невід'ємних частин. Необхідно вивчення взаємозв'язків i взаємозалежностей фінансової та економічної безпеки з позицій національних інтересів України. Виникає необхідність формування наукового апарату для визначення фінансово-економічної безпеки [2].

Під фінансово-економічною безпекою розуміється рівень розвитку фінансовоекономічної системи, який забезпечує формування необхідних умов для попередження внутрішніх суперечностей, подолання зовнішніх загроз, успішної реалізації інтересів держави, економічної стабільності, цілісності і єдності країни.

Внаслідок процесів дерегулювання і глобалізації відбувається розвиток фінансової сфери, яка змінює сутність самого фінансового ринку, надає йому статус особливого над економічного фінансового виробництва, що має свої унікальні технології, закони, ризики. Як наслідок слабшають економічні інструменти управління, змінюється схема розподілу доходів, багато інших базових економічних категорій змінюють свій зміст.

Головне протиріччя XXI століття - зростання диспропорції між потребами країн в забезпеченні темпів зростання економіки до темпів зростання населення i можливостями економіки в задоволенні цих потреб.

Внаслідок цього фінанси з звичайного механізму обслуговування економічних процесів перетворилися в найважливіший фактор сучасного розвитку економіки i суспільства. В умовах постійно зростаючої глобалізації та інтернаціоналізації роль фінансів в економічних та суспільних відносинах значно посилюється. Фінанси набули статус самостійного сегмента, якій визначає умови розвитку економіки [3].

Наслідком проведеної політики на теперішній час $є$ утворення істотного розриву між матеріально-речовими i фінансовими потоками. Фінанси відійшли від економічного базису і стали грати головну роль в устрої суспільно економічних відносин.

Фінансова система і фінансовий капітал трансформувалися 3 посередника, що обслуговує відтворення, в ключовий фактор його визначаючий. Диспропорції, які виникають внаслідок складності фінансових ринків, загострюють критичні суперечності в економіці, порушуючи відтворювальний процес і впливаючи на життєдіяльність суспільства. При цьому необхідно враховувати велику спекулятивну природу фінансів і їх мобільність, що несе в собі додаткові загрози і ризики для сталого розвитку національної економічної системи держави.

Останнім часом загострилися проблеми та загрози для фінансово-економічної безпеки, викликані суперечностями між суб'єктом і об'єктом, невідповідностями між 
фактичним i нормативним показниками системи. Спостерігається все зростаюча квазімонополістічна роль найбільших країн в світовій фінансовій системі, яка обумовлена політикою цих держав, спрямованої на стимулювання свого економічного зростання, викликаного або суто егоїстичними настроями суспільства і дедалі більшою схильністю до споживання, або істотними темпами зростання народонаселення. При цьому обмежені можливості щодо зростання реальної економіки викликають створення нових «фінансових бульбашок», приводячи до зростання аварій на фінансових ринках і загальносистемної волатильності.

Для вирішення даної проблеми необхідний перебудова системи зі сформованого незадовільного стану в стан можливості рішення проблем. Якщо дії виявляться недостатніми, то через деякий час буде реалізовано критичне відхилення і почнуться катастрофічні події незворотного характеру, що не дозволить перевести систему в цільовий стан, тобто в цьому випадку вирішити проблему вже буде неможливо [3],

Першими сигналами незворотності критичних відхилень системи є світова фінансова криза, яка продемонструвала не тільки суперечливість нововведень у фінансовій системі, таких як транснаціональний механізм мультиплікації грошей в економіці, ринок похідних фінансових інструментів і нових кредитних інститутів, в тому числі транснаціональних банків і холдингів, що з'явилися в 70-х роках минулого століття як механізми, що дозволяють стимулювати економічне зростання і долати обмеження державного регулювання ринкової економіки, а й критичні розміри сформованих диспропорцій, i в першу чергу розриву фінансових i товарноматеріальних потоків.

Ці нововведення і викликані ними диспропорції не тільки не дозволили вирішити суперечності, що виникли, але й стали джерелом дисбалансів загальносвітового рівня, перетворивши фінансову систему з інструменту стимулювання економічного зростання, в джерело загроз економічній системі, як в національному, так і на світовому рівні [2].

Сформоване протиріччя має сутнісний діалектичний характер і його розв'язання може або дати новий потужний імпульс розвитку суспільно-економічного устрою або привести ситуацію суспільно-економічну систему до повного краху. На проблемному рівні дані протиріччя можна інтерпретувати як проблему фінансово-економічної безпеки.

Спроби згладити виявлені суперечності у вигляді поширення глобалізації та інтернаціоналізації виробництва, мають лише тактичні успіхи, які надали можливість найбільшим світовим державам продовжувати ризиковану політику стимулювання власного добробуту за допомогою проведення дискримінаційної перерозподільній політики в світовому масштабі. Однак внаслідок проведеної політики відкритості фінансові та економічні ринки ще більшою мірою ускладнюються, їх поведінка вже не може бути пояснено виключно за допомогою існуючих теоретичних концепцій. Сучасна фінансово-економічна система вже увійшла в "невідому зону" - зону підвищеного ризику i нестабільного стану, яка насичена складними i різко загострюються проблемами загальносвітового масштабу. Отже, наростає потреба в прогнозуванні потенційних небезпек і загроз, в розробці діючих методів управління не тільки на державному, а й на загальносвітовому рівні. Системна організація даного процесу найкращим чином вписується в концепцію безпеки.

Варто відзначити необхідність зміни методів наукового пізнання і стратегії фінансово-економічної безпеки в умовах відкритості національної економіки держави. Традиційний підхід до вивчення фінансових і економічних ринків грунтується на 
розгляді їх як замкнутих систем з метою пошуку механізмів забезпечення стійкості, однорідності і порядку. Дані установки є підставою, що визначає традиційний спосіб вивчення процесів, що відбуваються в фінансах і економіці.

Однак в природі фінансові ринки і національні економіки є відкритими до самоорганізації системами, в яких відбувається вільний обмін із зовнішнім середовищем і з іншими подібними системами матеріальними і фінансовими потоками, інформацією. За допомогою взаємодії агентів всередині даних систем в умовах впливу конкуренції фінансово-економічна система стає активною, асиметричною.

Таким чином, нова методологія наукового пізнання відкритих фінансовоекономічних систем повинна враховувати відсутність стабільності, нелінійні відносини в даних системах. Зміна наукового підходу до пізнання призводить до зовсім нового тлумачення процесів, що відбуваються на фінансових і економічних ринках, змінює розуміння випадковості, необхідності та незворотності процесів і докорінно змінює уявлення про час [4].

В умовах зростаючої глобалізації фінансово-економічного ринку, міжнародного поділу праці, зростання міжнародної торгівлі і міжнародних інвестицій, відбувається ліквідація бар'єрів на шляху потоків товарів і ресурсів, транскордонного руху приватного та інституційного капіталу, які в свою чергу стають все більш важливою складовою глобальної економіки. На тлі збільшення обсягу i ролі міжнародних фінансово-економічних потоків і зв'язків, відбувається все більша інтеграція країн, як розвинених, так і країнах, що розвиваються, в глобальну фінансову систему, що в свою чергу сприяє збільшенню складності і вразливості всієї світової фінансово-економічної системи. Інтеграційні процеси, які відбуваються в глобальному масштабі, і є тим самим каталізатором, що загострює протиріччя між фінансово економічними процесами, що відбуваються останнім часом, що пояснюють їх теоріями і застосовуваної в їх розвиток управлінської методології та інструментарію.

Україна протягом останніх двох десятиліть все більше і більше залучається в процес глобалізації фінансово-економічної системи, а, отже, стає все більш відкритою як для використання переваг, які дає міжнародний фінансово економічний ринок, так і для тиску негативних загальносвітових тенденцій на розвиток національної економіки і фінансового ринку країни [2].

При цьому в результаті різкого переходу від централізованого регулювання економіки до ринкового механізму склалася ситуація, коли в країні зруйнована стара управлінська система, яка обслуговує закриту економіку країни, але при цьому не створені об'єктивні передумови і механізми для продуктивного, раціонального і рентабельного використання, тих переваг, які можуть виникати внаслідок підвищення відкритості національної фінансово економічної системи в масштабі економіки в цілому.

Сформована система державного управління не настроєна на досягнення зазначених вище передумов і в майбутньому. При цьому проводиться останнім часом курс на все більшу залученість національної економіки в систему світо господарських зв'язків, підвищує тим самим ії залежність від загальносвітової динаміки і кон'юнктури, несе в собі всі великі ризики збою національних фінансово-економічних систем. Що $\epsilon$ ключовою загрозою стійкості і безпеки національної фінансово-економічної системи $[5]$.

Все більша відкритість національної економіки та участь України в міжнародному обміні капіталом сприяє розтрачанню потенційних $\mathrm{i}$ реальних національних ресурсів, скорочує обсяг внутрішніх інвестицій і капіталовкладень, 
знижує можливості зростання вітчизняного виробництва $\mathrm{i}$ його структурної перебудови, порушує стійкість фінансових ринків, призводить до асиметрії основних його сегментів, негативно впливаючи на стан платіжного балансу, валютні резерви i курс гривні, вирішуючи ці питання на користь зарубіжних країн і зміцнюючи конкурентну міць своїх зарубіжних партнерів, в тому числі шляхом створення штучного попиту на більш дешеві міжнародні кредитні ресурси, на шкоду своїм глобальним економічним інтересам.

При цьому чіткі стратегії фінансово-економічного розвитку і побудовані з метою їх реалізації управлінські вертикалі і механізми, що дозволяють найбільшим світовим економікам і міжнародним організаціям реалізовувати свої економічні і геополітичні інтереси найбільш ефективним чином, досягаючи при цьому як довготривалих стратегічних цілей, так і повсякденних економічних переваг, представляють вагому загрозу інтересам національної безпеки України [2].

Зростаюча протягом десятиліття тенденція вивезення капіталу з України, як одного з найбільш значущих чинників економічного зростання, призводить до втрати значної частини економічних ресурсів, позицій на зовнішніх ринках і потенціалу до сталого розвитку [5]. Спостережувані в країні диспропорційності цінової політики на національних ринках тягнуть за собою структурну дисфункціональність всієї національної економіки і суттєві загрози для її сталого розвитку, особливо в умовах високої волатильної динаміки, що спостерігається останнім часом і має переважно екзогенну природу. Дана ситуація загострюється істотною неоднорідністю розвитку країни, як в економічній, так і в соціальній сфері, громадським розшаруванням, що провокує виникнення безлічі соціально-економічних загроз безпеки і цілісності України.

Всі ці фактори в істотному ступені знижують «національну силу» держави, тобто його роль на світовій арені (в т.ч. у фінансовій, економічній, науково-технічній та ін. областях), рівень стійкості до кризових впливів, в т.ч. загальносвітових, а також силу національного лобі в загальносвітовому масштабі [4].

В умовах, що склалися в Україні, необхідна єдина комплексна система управління рівнем національної сили держави, яка грунтується на економічному та соціальному благополуччі свого народу. Особливу роль в даному процесі має відігравати система управління геоекономічної фінансовою стабільністю і фінансовоекономічним розвитком країни в умовах високих системних ризиків i сильною інтеграційної відкритості, заснована не на тактичних показниках і цілях, а на стратегічних національних інтересах і управлінні процесами самоорганізації відкритих, нерівноважних, нелінійних систем [3].

Сформована до теперішнього часу інституційна структура забезпечення національної безпеки не інтегрована $з$ процесами, які відбуваються у фінансовій сфері та економіці країни, атомістична структура управління (в тому числі без виділення окремого блоку управління фінансово-економічною безпекою), не дозволяє забезпечити ефективну реалізацію стратегії національної безпеки та скорочення розриву між стратегією безпеки, як основоположним документів, і iї тактичною реалізацією.

Крім того для побудови та ефективного функціонування вертикально інтегрованої децентралізованої системи управління фінансово-економічною системою в інтересах національної безпеки необхідний сучасний теоретико-методологічний базис. Оскільки останні кризові прояви викривають недоліки і протиріччя неокласичної економіки і доводять небезпеку формування догм, які не мають нічого спільного 3 
реальністю [3]. Однак до теперішнього часу превалює позиція економістів, які вважають за можливе дотримуватися нехай навіть неправдоподібної, але зате добре відпрацьованої теорії абсолютно раціональних агентів, ніж заглиблюватися в нескінченному моделюванні ірраціональної поведінки агентів.

При цьому слід врахувати, що теоретичні концепції розглядаються багатьма політиками і економістами як обгрунтування проведеної ними політики і прийнятих рішень, передумови теорій економічної рівноваги і раціональних очікувань, і надали продовжують здійснювати істотний вплив на управлінські рішення світової політичної і економічної еліти, що є передумовою, а не наслідком формування понад волатильної світової кон'юнктури з дедалі більшою ентропією [4].

До цих пір більшість політиків намагаються боротися 3 дисбалансами в економіці, існуючими заходами i, виходячи з логіки неокласичної школи, як правило, на локальному або регіональному рівні, для досягнення, як вони вважають, основний мети - рівноважного стану економіки, необхідного для забезпечення глобального економічного підйому, зростання торговельних потоків і зайнятості, витрачаючи масу зусиль і коштів, але розвиток економіки протягом останніх років наочно демонструє, що диспропорції ринків, глибина сплеск в і провалів, а також їх частота тільки зростає.

Відсутність теоретико-методологічних основ ефективного управління економікою України та збереження національних інтересів в умовах підвищеної волатильності світової системи і їі високого ступеня інтеграції, яка враховує складну колективну не рівноважну динаміку розвитку сучасних систем, засновану, в тому числі на ірраціональному поведінці економічних агентів, в першу чергу робить «сліпими» більшість економістів в забезпеченні стабільного розвитку економічної системи і не дозволяє ефективно управляти зростаючою проціклічністю і волатильністю ринків, в яких $\epsilon$ істотні розриви між фінансово-економічними процесами зі складною динамікою (цикли, нерегулярні флуктуації, хаос, провали і т.п. і існуючими теоріями), які в свою чергу:

- не враховують тимчасову змінну, людський фактор, зокрема психологію і поведінкові стратегії людини, місце, особливості географічного положення, тенденцій розвитку регіонів, та ін., I їх взаємозв'язок один з одним;

- лінійні, описують стаціонарні стани і вірні, як правило, тільки в умовах короткочасного рівноваги і виключно на мікрорівні;

- не універсальні, теорія, яка намагається пояснити довготривалу економічну еволюцію, швидше за все, безсила пояснити короткочасні економічні явища;

- останнім часом економіка, як і економічна теорія, грунтуються на досить спрощених для забезпечення збіжності результатів економічних моделях, які добре працюють в стані рівноваги, а в нерівноважному середовищі описати ці процеси не можуть.

При цьому більшість економістів досі повністю поділяє точку зору, що:

- ринки дозволяють забезпечувати оптимальний розподіл ресурсів, включаючи людські;

- дієвість раціональної теорії (наприклад, стосовно безробіття і т.д.);

- будь-якими обмеженнями («недосконалостями») ефективно управляє ринок (дерегулювання).

Так, в процесі розвалу системи централізованого планування в країнах колишнього СРСР багато політиків та економістів, незважаючи на те, що з'явилися публікації західних вчених, які містять активну критику і опис недосконалостей традиційно ліберальних уявлень про ринок і його наслідки, сліпо вірили в те, що 
демонтаж старої системи управління і надання індивідам можливості діяти, виходячи 3 ï егоїстичних інтересів, автоматично збудує таку ринкову систему, яка забезпечить більш раціональне і ефективне функціонування національної економіки. А перехід на ринкові умови побудови економічних відносин, що базуються на західній «політичної економії», тобто неокласичної економічної теорії, забезпечить країнам ліквідацію алогізмів, властивих колишньої системи державного планування, спрямованої одночасно на гарантоване підвищення рівня життя і економічне зростання, і буде служити гідною заміною марксизму. При цьому не потрібно створювати нову теоретико-методологічну систему управління національною економікою, засновану на національних інтересах і враховуючу національні особливості, місце та роль економіки України в світі.

Вибір на користь неокласичної економічної теорії був обумовлений iї позиціонуванням як ефективний механізм, що дозволяе мінімізувати нестійкість ринкового укладу господарювання, викликану вільним індивідуальним вибором розумних індивідів, за допомогою зв'язування ідеї ефективності, раціональності й порядку в соціальній та економічній організації суспільства 3 поняттями «свободи особистості», «індивідуального вибору » і «індивідуальної раціональності» [5]. Теоретики неокласичної школи стверджують, що їхня концепція за допомогою максимальної ефективності та економічності використання дефіцитних ресурсів створює організовані ринки, які забезпечують більш ефективний розподіл суспільних ресурсів, ніж будь-яка альтернативна теорія. Як доказ цього твердження наводяться історичні дані про те, що в країнах, економіка яких організована за принципом вільного ринку, спостерігається найвищий рівень зростання виробництва i розширення добробуту населення. Насторожує той факт, що неокласична теорія при цьому не приділяє достатньо уваги теорій зростання, обгрунтовуючи їх вельми спірним феноменом, який визначається як «рівноважний зростання» i концентрується переважно на обгрунтуванні ефективності ринку як механізму розподілу наявних ресурсів, ніж в поясненні джерел зростання цих ресурсів [5].

При цьому неокласична теорія, розглядаючи максимізує корисність економічних агентів, раціонально діючих у власних інтересах, не досліджує і не враховує той факт, що взаємодія даних агентів, незалежно від інституційних рамок, в яких вона здійснюється (тим більше, якщо такі рамки в принципі відсутні ), як наслідок ендогенної динаміки, не завжди призводить до стійкого і суспільно корисного результату [4].

Незважаючи на вищевказане, прихильники неокласичної школи, позиціонують цю теорію як універсальну модель для пояснення економічних феноменів і суспільного життя, і використовують ії як теорію суспільної поведінки людей, вважаючи за можливе екстраполювати припущення теорії раціонального вибору на безліч альтернативних сценаріїв і умов функціонування фінансово-економічних систем, а також пристосовувати їх для використання поза сферою політичної економіi [4].

Також відзначимо, що провідні світові держави, які пропагують в економіках, що розвиваються, принципи вільного ринку і є апологетами неокласичної економічної школи, грунтуються в практиці управління своїми національними фінансово економічними системами на останніх досягненнях теорії раціонального вибору, що ставить під сумнів ліберальні концепції вибору, свободи, раціональності індивіда і визнає, що індивіди існують і роблять вибір в рамках соціально структурованої середовища і характер цих структур (i те, як вони усвідомлюються індивідуумами) має безпосередній вплив, як на прийняті індивідами рішення, так і на наслідки цих рішень. 
При цьому в розвинених країнах все більш увага приділяється проблемі інституційної вбудованості індивідуальної дії, обумовленої впливом комплексу складових системних елементів: юридично оформленого середовища, норм соціально прийнятої і суспільно значущої поведінки, уявлень про те, що відповідає егоїстичним інтересам в розширеному часовому контексті, моделювання та забезпечення інтеграції різних типів індивідуальної діяльності в створене середовище (за допомогою формування дизайну такого середовища, створення необхідної топології зв'язків i забезпечення належного когерентної взаємодії) відповідно до національних інтересів розвинених економік.

Віра в застарілі економічні теорії, які пропагують принцип «laissez-faire», в умовах відсутності методологічної основи управління національної економікою, що враховує національні інтереси і особливості, місце та роль економіки України в світі, істотно впливає на стійкість розвитку національної фінансово-економічної системи, а також рівень загроз фінансово-економічної безпеки України [5].

Висновки. 3 огляду на вищевикладене, можна сказати, що для досягнення стійкого економічного зростання, підвищення конкурентоспроможності української промисловості, поліпшення структури ввезеного i вивезеного капіталу i його географічної спрямованості, що відповідає національним інтересам України, а також скорочення каналів витоку капіталу з країни, усунення загрози внутрішнього розколу країни внаслідок зростаючої диспропорційності фінансово-економічного розвитку, загострення соціальних проблем та ін., назріла нагальна необхідність на підставі новітніх загальнонаукових досягнень побудування нової конструктивно-філософської основи і методології управління національною фінансово-економічною відкритою системою, яка повинна бути заснована на принципах системності, яка б могла протистояти дестабілізуючому впливу зростаючих екзогенних загроз, негативної світової динаміки розвитку, при цьому дозволяла б забезпечити умови для сталого ендогенного зростання національної фінансово-економічної системи країни.

\section{Література:}

1. Закон України «Про основи національної безпеки України». - [Електронний pecypc] - Режим доступу: http://zakon.rada.gov.ua/cgi-bin/laws/main.cgi ?nreg=964-15

2. Деменок О. В. Бюджетна безпека України як одна з складових фінансової безпеки держави. [Електронний ресурс] - Режим доступу: http://www.rusnauka.com

3. Матвєєв В. В., Селіверстова І.О., Гавриленко О.А. Податкова безпека як елемент фінансової безпеки держави. - [Електронний ресурс] - Режим доступу : http://www.nbuv.gov.ua/ejournals/

4. Методика розрахунку рівня економічної безпеки України, затверджена наказом Міністерства економіки України № 60 від 02.03.2007 р. [Електронний ресурс] - Режим доступу: http://www.me.gov.ua/control/uk/

5. Наконечна Н. В. Тенденції індикаторів фінансової безпеки України. [Електронний ресурс]- Режим доступу: http://www.newsru.ua/finance/12sep2011/

6. Стан енергетичної безпеки України (оцінка та методологія розрахунку). [Електронний ресурс] - Режим доступу: http://www.niss.gov.ua/public/File/ 2012 